In Memoriam

\title{
RIHARDS KONDRATOVIČS (1932-2017), LATVIAN RHODODENDRON BREEDER
}

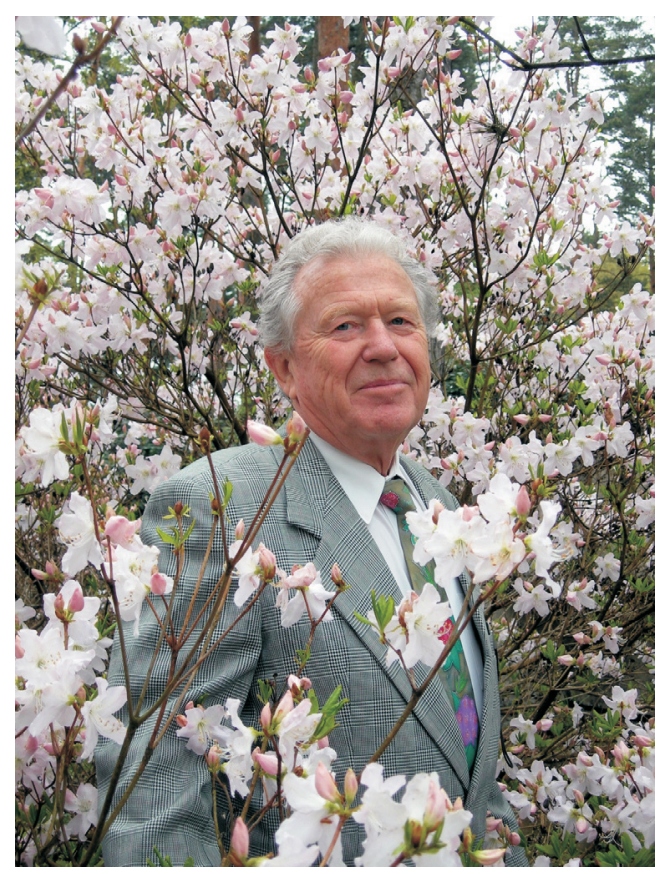

Rihards Kondratovičs, full member of the Latvian Academy of Sciences since 1992 (corresponding member from 1989), a famous Latvian rhododendron breeder, passed away on 17 February 2017, at the age of 84 .

Rihards Kondratovičs was born on 12 May 1932 in a family of five children. His childhood was that of the real rural child — his father was a forester, while his mother managed the household, taking care of children and the farm. The children had to help with the daily work - weed the garden, provide firewood to cook food for livestock, to feed them. Apparently the bitterness of childhood's daily work was the reason for his later hard-working life, without sparing himself, with productive work.

Rihards Kondratovičs launched his education in 1939 in a small country school - Kalēji primary school, where he finished six classes. Due to the war events, the whole family was forced to move to Kurzeme, because his father was appointed to the Andumi Forest Management Unit of Kandava District. Rihards continued education in Talsi Secondary school. Later in life when evaluating his high school years, he admits that it was at that time he gained interest in natural processes, based on nature education taught by an excellent teacher and naturalist V. Dreimanis, under whose leadership experimental fields were planted with crop collections and plant crossings were made to develop new crop varieties. The knowledge and skills obtained after high school graduation allowed Rihards Kondratovičs to choose studies at the Faculty of Biology, Latvian State University, where he studied from 1950 to 1955 , obtaining the qualification of a biologist — plant physiologist, biology and chemistry teacher.

Only two months after the graduation, he began work as a laboratory assistant at the Department of Human and Animal Physiology, Faculty of Biology. Subsequently, the young specialist was appointed by the Latvian State University (LSU) rector's order as director of the Botanical Garden, LSU. The Botanical Garden was his first serious workplace and career challenge, but it is more important that during this time Rihards Kondratovičs focused on a new ornamental woody plant culture - rhododendron research. It is possible that the successful start of rhododendron research in Latvia at that time was based on a timely issue of plant introduction and acclimatisation, which has since not lost its relevance.

In fact, the beginning of research on the genus Rhododendron in Latvia should be considered the year 1957, when Rihards Kondratovičs launched rhododendron introduction work at the Botanical Garden, LSU, initially in a short time by assessing suitability of about 400 wild rhododendron species for growth in Latvian climate conditions. This work resulted in the selection of 100 species suitable for growth in Latvia. The most important results of the first seven years 
of work were presented in the Candidate of Science thesis "Rhododendron introduction in the Latvian SSR", which in 1964 was successfully defended by Rihards Kondratovičs at the Scientific Council meeting of the Faculty of Biology, LSU, leading to the scientific degree of the Candidate of Biological Sciences. The research results were the basis for further work on breeding of new ornamental and hardy rhododendron cultivars suitable for growing in the climatic conditions of Latvia. In addition to outdoor rhododendron breeding work, Professor Rihards Kondratovičs also performed the collection and breeding of Rhododendron simsii (greenhouse azalea), thus leading to the present collection of the Botanical Garden, University of Latvia, which includes 126 varieties of azaleas, including 26 bred in Latvia.

In 1965, after ten years spent in the Botanical Garden of the University of Latvia, Rihards Kondratovičs was appointed the Dean of the Faculty of Biology, which was a new challenge for administrative work. This year was very difficult for the Faculty of Biology, because during the overhaul of the building in Friča Gail,a Street 10, fifty wood-burning brick stoves were demolished so that a central heating system could be installed, without interrupting the study process. The job of dean, working together with a collective of peers and former fellow students, as well as academic work with teaching students, gave him great satisfaction. However, the large administrative burden was not an obstacle to continuing study of Rhododendron, which had already entered a new level — breeding. Rihards Kondratovičs was the leader of study courses in Plant Anatomy, Plant Introduction and Breeding, and Plant Resistance Physiology Based on Immunity. The present rector of the University of Latvia, Professor Indrikis Muižnieks, still remembers his first laboratory work, on the onion cell, in Plant Anatomy led by Rihards Kondratovičs in 1971. Later he formed the laboratory of Plant Physiology, where along with colleagues performed anatomical, morphological and biochemical studies of Rhododendron.

The complex studies on Rhododendron in Latvia were summarised in the monograph Rhododendrons in Latvian SSR. Biological Basis of the Culture, which was defended in 1983 in the Main Botanical Garden of the Academy of Sciences, USSR, as a dissertation for obtaining the Degree of the Doctor of Biological Sciences. Two years later, he was elected as Professor of the Latvian State University.

It should be noted, in the 1970s and 1980s, Rihards Kondratovičs wrote a monograph on rhododendron Azaleas, published in Latvian and Russian, as well as a textbook Practical Studies in Plant Anatomy.

A turning point in the study of Rhododendron in Latvia was in 1976, when the State Government designated 12.1 hectares of pine forest for developing a specialised rhododendron nursery, to the Latvian State University. In 1980, the Experimental Rhododendron Breeding Nursery "Babīte" was established officially, with its creation and management entrusted to Rihards Kondratovičs. The aim of the nursery was to create ornamental and winter-hardy rhododendrons.
The next challenge for his academic work began in 1987, when the newly elected Latvian State University rector Juris Zakis invited Professor Rihards Kondratovičs to the post of vice-rector of science. Until 1997, he was leader of the organisation of research at the University of Latvia, financing of research, and creation of habilitation and promotion councils, which carried out nostrification. He was also responsible for the student fraternities and sororities to be reinstated. In fact, this work was associated with the operational restructuring of the University in conditions of the renewed Latvian independence and the new free market economy.

In spite of the heavy administrative burden, the new established Rhododendron nursery "Babīte" continued rhododendron breeding work and, from 1999, the work began to bear fruit - the first nine certificates for outdoor rhododendron cultivars registration were registered, and today University of Latvia and the whole country can be proud of 109 local bred outdoor rhododendron cultivars, all of which are registered in the International Rhododendron Register and Checklist published by the Royal Horticultural Society, Great Britain. It should be noted that many of the cultivars are named after respect for people and organisations that provided support to Professor Rihards Kondratovičs research. The University of Latvia is proud today to have a collection of 76 wild rhododendron species and 265 cultivars, as well as 126 varieties of greenhouse azalea.

In his working life Rihards Kondratovičs has written more than 630 publications, including 7 monographs, 1 textbook, 4 training tools, and has supervised 5 doctoral theses, 19 diploma, and 35 course theses.

Activities of Professor Rihards Kondratovičs work in national and international scientific associations cannot be forgotten - he was a full member of the Latvian Academy of Sciences and the European Academy of Sciences and Arts, a member of many foreign rhododendron growers societies, journal editorial boards and community councils, a member of societies of Latvian Dendrologists, Landscape Architects, Botanists, Geneticists and Breeders, and Gardeners and Beekeepers associations, a board member of the club "Emeritus" and a member of the Latvian Republic State Emeritus Scientists Council.

Rihards Kondratovičs received numerous awards for his scientific and public activities: three Soviet Union People's Economic Achievements Exhibition gold medals, the Order "Badge of Honor', the Latvian SSR State Prize, Diploma of the Ministry of Education and Science, the Order of Three Stars, the Fatherland Award, the Grand Medal of Latvian Academy of Sciences, the Award of the Latvian Academy of Sciences, and the stock company "Itera", the Award of the Riga City Council and the Latvian Academy of Sciences, as well as several dozens of gratitude and appreciation certificates of the University of Latvia. He was the Latvian State Emeritus Scientist, Professor Emeritus of the University of Latvia, and the Man of the Year of the Uni- 
versity of Latvia in 2010 for establishment of a scientific school.

Rihards Kondratovičs was an independent and creative man with brilliant organisational skills and enormous capacity for hard work. At the same time he was simple, very kind and sincere person with a good sense of humour.

Rihards Kondratovičs was a lucky person because of his Family. Already many times stressed above, rhododendrons were Professor's Rihards Kondratovičs lifelong love in science, thanks to which his work is recognisable not only in Latvia, but also in Europe and all over the world. However, as admitted by him, only the support of family can help a person to be creative and productive. He received lifelong support from his wife Skaidrīte, as well from his children - daughter Ginta and son Uldis, both of whom are also biologists. Skaidrìte's merit, at first, was taking care of the children and their education, household maintenance, and she spent most of her working life as a scientific editor at the publishing house "Zvaigzne", and Rihards Kondratovičs believed that without her support, participation and understanding, Latvia would lack rhododendrons.

Professor Rihards Kondratovičs deserves to be the king of rhododendrons in Latvia and his working life has set high standards for rhododendron breeders in Latvia.

Uldis Kondratovičs

\section{RIHARDS KONDRATOVIČS (1932-2017), LATVIJAS RODODENDRU SELEKCIONĀRS}

2017. gada 17. februārī mūžībā aizgāja akadēmiḳis, LZA Lielās medaḷas laureāts, LU profesors Rihards Kondratovičs.

Rihards Kondratovičs dzimis 1932. gada 12. maijā Daugavpils apriņķa Asūnes pagastā piecu bērnu ğimenē. Viņa bērnība pagāja kā īstam lauku bērnam - kamēr tēvs katru rītu devās darbā mežniecībā, bet māte saimniekoja pa māju, aprūpējot bērnus un kopjot saimniecību, bērniem vajadzēja palīdzēt ikdienas darbos — ravēt dārzā nezāles, gādāt malku, gatavot ēdienu mājlopiem, ganīt tos. Acīmredzot jau bērnībā iepazìtais ikdienas darba sūrums bija pamatā tam, lai savā vēlākajā darba mūžā viņšs, sevi nežēlodams, ražīgi strādātu, un darbs, kā zināms, agri vai vēlu nes saldus augḷus.

Skolas gaitas Rihards Kondratovičs uzsāka 1939. gadā nelielā, tam laikam tipiskā lauku skolin̄ā — Kalēju pamatskolā, kur pabeidza sešas klases, bet sakarā ar kara notikumiem visa ǵimene bija spiesta pārcelties uz Kurzemi, jo tēvu pārcēla darbā uz Kandavas virsmežniecības Andumu mežniecību. Izglīīibu Rihards Kondratovičs turpināja Talsu vidusskolā un, vêrtējot vidusskolā pavadītos gadus, pats atzīst, ka to laikā guvis interesi par dabā notiekošajiem procesiem, jo dabas mācību pasniedza lielisks pedagogs un dabas pētnieks V. Dreimanis, kura vadībā ierīkoti izmēgeinājumu lauki ar kultūraugu kolekcijām, veikti dažādi augu krustojumi, lai iegūtu jaunas kultūraugu formas. Iegūto zināšanu un prasmju iespaidā pēc vidusskolas absolvēšanas Rihards Kondratovičs izvēlējās studijas Latvijas Valsts universitātes Bioloğijas fakultātē, kur studēja no 1950. līdz 1955. gadam, iegūstot biologa - augu fiziologa, biologiijas un kīmijas skolotāja kvalifikāciju.

Tikai divus mēnešus pēc universitātes absolvēšanas nostrādājis par laborantu Bioloǵijas fakultātes Cilvēka un dzīvnieku fizioloǵijas katedrā, jaunais speciālists ar LVU rektora Jāņa Jurgena pavēli tika iecelts par LVU Botāniskā dārza direktoru. Botāniskais dārzs Rihardam Kondratovičam bija pirmā nopietnā darba vieta un karjeras izaicinājums, tomēr vissvarīgākais šis laiks viṇa darba mūžā ir tāpēc, ka tad viṇš pievērsās Latvijai tam laikam jaunas augu kultūras — rododendru izpētei. Iespējams, ka darba veiksmīgam sākumam pamatā bija tajā laikā valsts mērogā priekšplānā izvirzìtais augu introdukcijas un aklimatizācijas jautājums, kas aktualitāti nav zaudējis arī mūsdienās.

Faktiski par rododendru ğints apzinātu un zinātniski pamatotu pētījumu sākumu Latvijā jāuzskata 1957. gads, kad LVU Botāniskajā dārzā Riharda Kondratoviča vadībā tika sākts rododendru introdukcijas darbs, sākotnēji īsā laikā pārbaudot aptuveni 400 rododendru savvaḷas sugu piemērotību augšanai Latvijas klimata apstākḷos, un šī darba rezultātā atzīstot tikai 100 sugu piemērotību augšanai Latvijā. Tomēr pats svarīgākais bija, ka pirmo septiṇu gadu darba rezultāti tika apkopoti zinātṇu kandidāta disertācijā "Rododendru introdukcija Latvijas PSR", kuru 1964. gadā Rihards Kondratovičs aizstāvēja LVU Bioloğijas fakultātes Zinātniskās padomes sēdē, iegūstot bioloğijas zinātṇu kandidāta zinātnisko grādu. Pētījumu rezultāti bija pamatā tam, lai varētu uzsākt rododendru kultūras selekciju — jaunu, Latvijas klimata apstākḷiem piemērotu škiinnu veidošanas darbu. Līdzās brīvdabas rododendru selekcijas darbam profesors Rihards Kondratovičs šajā laikā uzsāka arī Simsa rododendru jeb siltumnīcu acāliju kolekcijas veidošanu un arī selekciju, kā rezultātā līdz šodienai LU Botāniskā dārza kolekcijā ir 126 acāliju šķirnes, tajā skaitā arī 26 Latvijā izveidotas šḳirnes.

Pēc desmit Botāniskajā dārzā pavadītajiem gadiem Rihardu Kondratoviču ar LVU rektora pavēli iecēla par Bioloğijas fakultātes dekānu, kas bija jauns pārbaudījums administratīvajā darbā. 1965. gads Bioloǵijas fakultātei bija ḷoti smags, jo kapitālā remonta laikā Friča Gaiḷa ielā 10, nepārtraucot studiju procesu, bija jānojauc pussimts malkas apkures krāšṇu un jāierīko centrālā apkure. Kā atzīst Rihards Kondratovičs, dekāna darbs vienaudžu un bijušo studiju biedru kolektīvā, kā arī darbs ar studentiem viṇam sniedza lielu gandarījumu, tomēr būtiskākais ir, ka arī lielā administratīvā slodze nav biju par šķērsli turpināt rododendru ǵints pētījumus, kas nu jau bija iegājuši jaunajā — selekcijas lìmenī. Rihards Kondratovičs Bioloǵijas fakultātē mācīja studiju kursus "Augu anatomija”, "Augu introdukcijas un selekcija”, "Augu izturības fizioloǵijas ar imunitātes pamatiem". Pašreizējais LU rektors profesors Indriķis Muižnieks joprojām atceras savu pašu pirmo laboratorijas darbu augu anatomijā — sīpola epidermas šūnu izpēti, ko 1971. gadā vadīja Rihards Kondratovičs. Strādādams dekāna amatā, viṇš izveidoja Augu fizioloǵijas laboratoriju, kurā kopā ar kolēǵiem veica rododendru ǵints anatomiskos, morfoloğiskos un biokīmiskos pêtījumus, krāja rododendru ǵints kompleksās izpētes materiālus un tos analizēja.

Minētais darbs bija pamatā monogrāfijas "Rododendri Latvijas PSR. Kultūras bioloǵiskie pamati” sarakstǐšanai, kuru Rihards Kondratovičs 1983. gadā PSRS Zinātņu akadēmijas Galvenajā botāniskajā dārzā Maskavā aizstāvēja kā disertāciju biolog̣ijas zinātṇu doktora zinātniskā grāda iegūšanai. Savukārt 1985. gadā viṇu LVU ievēlēja profesora amatā. 
Jāatzīmē, ka pagājušā gadsimta 70. un 80. gados zinātniskās darbības rezultātā Rihards Kondratovičs sarakstīja vēl divas grāmatas par rododendriem - monogrāfiju "Acālijas" latviešu un krievu valodās, kā arī mācību grāmatu "Augu anatomijas praktikums”.

Par pavērsienu rododendru ğints kompleksajā bioloǵiskajā izpētē Latvijā jāuzskata 1976. gads, kad ar LPSR Ministru padomes lēmumu Nr. 202 Latvijas Valsts universitātei piešḳīra 12,1 ha lielu priežu meža platību specializētas rododendru selekcijas un izmēǵinājumu audzētavas organizēšanai, savukārt 1980. gada 1. jūlijā ar LVU rektora V. Millera pavēli Nr. 86 oficiāli tika nodibināta LVU Rododendru selekcijas un izmēǵinājumu audzētava "Babīte".

Nākamais izaicinājums Riharda Kondratoviča darba mūžā sākās 1987. gadā, kad pēc jaunievēlētā LVU rektora Jura Zaķa uzaicinājuma profesors sāka strādāt par zinātnu prorektoru, līdz 1997. gadam organizējot universitātes zinātnisko darbību — risinot zinātnes finansēšanas jautājums, veidojot habilitācijas un promocijas padomes, kurām jāveic nostrifikācija. Tāpat bija jāatbild par studentu korporāciju darbības atjaunošanu. Faktiski šis darbs bija saistīts ar LU darbības pārstrukturēšanu atjaunotajā Latvijas brīvvalstī jaunajos brīvā tirgus ekonomikas apstāklıs.

Neraugoties uz lielo administratīvo slogu, jaunajā Rododendru selekcijas un izmēǵinājumu audzētavā "Babīte" tika turpināts rododendru selekcijas darbs un, sākot ar 1999. gadu, šis darbs sāka nest aug̣̣us — tika iegūtas pirmās deviņas autorapliecības par brīvdabas rododendru škirṇu izveidi, savukārt šodien Latvijas Universitāte un visa Latvija jau var lepoties ar 109 vietējās selekcijas brīvdabas rododendru škirnēm, kuras visas ir reǵistrētas Karaliskās Dārzkopības biedrības (Lielbritānija) uzturētajā Starptautiskajā rododendru škirṇu reǵistrā. Jāatzīmē, ka daudzām šķirnēm ir dots vārds, apliecinot cieṇu cilvēkiem un organizācijām, kas ir sniegušas dažāda veida atbalstu profesora Riharda Kondratoviča pētniecības darbā. Tāpat Latvijas vārds ir slavens ar to, ka Latvijas Universitāte šodien lepojas ar 76 savvaḷas rododendru sugu un 265 šķinnu, kā arī 126 siltumnīcu acāliju šķirṇu kolekciju.

Savā darba mūža Rihards Kondratovičs uzrakstīijis vairāk nekā 630 publikāciju, tajā skaitā 7 monogrāfijas, 1 mācību grāmatu, 4 mācību līdzekḷus, ir vadījis 5 disertāciju, 19 diplomdarbu un 35 kursa darbu izstrādi.

Nevar neizcelt profesora Riharda Kondratoviča aktīvo darbu starptautiskās un nacionālās zinātniskajās apvienībās — viņ̌̌ bija Latvijas Zinātṇu akadēmijas īstenais loceklis, Eiropas zinātnu un mākslas akadēmijas loceklis, daudzu ārvalstu rododendru audzētāju biedrību biedrs, žurnālu redkolēǵiju un sabiedrisko padomju loceklis, Latvijas Dendrolog̣ijas, Ainavu arhitektu, Botāniķu, G̦enētiku un selekcionāru, Dārzkopības un biškopības biedrību biedrs, kluba "Emeritus" valdes loceklis, kā arī Latvijas Republikas Valsts emeritēto zinātnieku Padomes loceklis.

Par savu zinātnisko un sabiedrisko darbību Rihards Kondratovičs saṇēmis neskaitāmus apbalvojumus — trīs Vissavienības Tautas saimniecības sasniegumu izstādes zelta medaḷas, ordeni "Goda zīme”, LPSR Valsts prēmiju, LR Izglītības ministrijas Atzinības rakstu, Triju Zvaigžņu ordeni, Tēvzemes balvu, LZA un A/S "Itera” balvu, LZA Lielo medalı,u, Rīgas domes un LZA balvu, kā arī vairākus desmitus Latvijas Universitātes pateicību un atzinības rakstu. Viņš bija Latvijas Valsts emeritētais zinātnieks, LU emeritētais profesors, LU gada cilvēks 2010. gadā par zinātniskās skolas izveidošanu.

Rihards Kondratovičs bija neatkarīgs un radošs cilvēks ar izcilām organizatora un smaga darba spējām. Tajā pašā laikā viņš bija vienkāršs, loti laipns, atklāts un tiešs cilvēks ar lielisku humora izjūtu.

Bet viņa mūžā pats svarīgākais tomēr bija Ģimene. Jau neskaitāmas reizes ir uzsvērts, ka profesora Riharda Kondratoviča mūža mīlestība zinātnē bija rododendri, kuriem pateicoties viṇa darbs šodien ir atpazīstams ne vien Latvijas, bet arī Eiropas un pasaules mērogā. Tomēr, kā viņš pats atzīst, lai cilvēks varētu radoši un ražǐgi strādāt, viṇam vispirms ir nepieciešams ğimenes atbalsts. To viņ̌s visa mūža garumā ir guvis no savas dzīvesbiedres Skaidrītes, kā arī no saviem bērniem - meitas Gintas un dēla Ulda, kuri visi tāpat ir biologi. Skaidrītes nopelns vispirms, bija rūpes par bērniem un vinu audzināšanu, mājsaimniecības uzturēšana, vienlaikus lielāko daḷu sava darba mūža strādājot par zinātnisko redaktori izdevniecībā "Zvaigzne”, un pats Rihards Kondratovičs uzskata, ka bez viņas palīdzības, līdzdalības un sapratnes, Latvijā nebūtu arī rododendru.

Profesors Rihards Kondratovičs ir pelnījis, lai viṇu sauktu par Latvijas rododendru karali, un viṇa darba mūžs ir uzstādījis ḷoti augstus standartus rododendru selekcionāriem Latvijā. 